\title{
THE EXPERIMENTAL STUDY ON STICK-SLIP PROCESS OF BENDING FAULTS
}

\author{
Y. S. H. Guo ${ }^{1}$, J. Ma ${ }^{1}$, L. Yun ${ }^{1}$, S. A. Bornyakov² \\ ${ }^{1}$ State Key Laboratory of Earthquake Dynamics, Institute of Geology, China Earthquake Administration, \\ 100029, Beijing, China \\ ${ }^{2}$ Institute of the Earth's Crust, Siberian Branch of RAS, 664033, Irkutsk, Lermontov street, 128, Russia
}

\begin{abstract}
The stick-slip process of bending faults with one angle change of $5^{\circ}$ at the connection location between the two line fault segments is investigated in this paper. The dynamic process and physical field evolution were observed in the laboratory, and measurements were recorded with application of fault displacement measurement, strain tensor analysis and acoustic emission (AE) techniques. The experimental results from the study of bending faults give grounds for the following primary conclusions: (1) It is clearly revealed that there is a negative correlation between the logarithms of the stick-slip cycle and loading rate; (2) With different loading rates, most of the instabilities from bending faults occurred as earthquake doublets. It means that an instable event can contains two sub-events which occur with an interval of time from $100 \mathrm{~ms}$ to 200 ms. (3) With application of different observation approaches, regardless of the fact that the sampling rates were the same, differences of the co-seismic response were observed. For instance, strain measurements indicated significant strain weakening stage, but fault displacement was not significantly changed before fault instability. (4) Experimental studies of high sampling rates contribute to a better understanding and awareness of earthquake precursors and the seismogenic process; such studies are helpful in analyzing the mechanism of strong earthquake processes and parameters of aftershocks.
\end{abstract}

Key words: bending faults; stick-slip process; earthquake doublets; physical field.

Recommended by V.V. Ruzhich 3 February 2011

Citation: Guo Y.S.H., Ma J., Yun L. The experimental study on stick-slip process of bending faults // Geodynamics \& Tectonophysics. 2011. V. 2. № 1. P. 35-44.

\section{ЭКСПЕРИМЕНТАЛЬНОЕ ИЗУЧЕНИЕ ПРОЦЕССА ПРЕРЫВИСТОГО СКОЛЬЖЕНИЯ ПО РАЗЛОМАМ С ИЗГИБОМ}

\author{
Ю. С. Х. Гуо ${ }^{1}$, Дж. $\mathrm{Ma}^{1}$, Л. Юн ${ }^{1}$, С. А. Борняков ${ }^{2}$ \\ 1 Лаборатория динамики землетрясений, Институт геологии, 100029, Пекин, Китай \\ ${ }^{2}$ Институт земной коры СО РАН, 664033, Иркутск, ул. Лермонтова, 128, Россия
}

\begin{abstract}
Аннотация: В данной статье описаны эксперименты по изучению процесса прерывистого скольжения по разломам с изгибом с изменением направления под углом $5^{\circ}$ в точке соединения двух участков данного разлома. В лабораторных условиях для изучения динамики и параметров развития физических полей применялись методики замера смещений по разломам, анализа тензора деформаций и акустической эмиссии (АЭ). По результатам экспериментов по изучению разломов с изгибом было выявлено следующее: 1. Четко установлена негативная корреляция между логарифмом цикла прерывистого скольжения и величиной нагрузки. 2. При различной величине нагрузки большинство нарушений стабильности на разломах с изгибом были проявлены как землетрясения-дублеты. Это означает, что одно событие нарушения стабильности состоит из двух подсобытий. Временной интервал между двумя подсобытиями
\end{abstract}


варьируется от 100 до 200 мс. 3. При разных подходах к наблюдению, несмотря на одинаковую частоту выборки, отмечается различие косейсмической реакции (по замерам деформации была выявлена фаза значительного уменьшения деформации, однако длина смещения по разлому существенно не изменилась перед нарушением стабильности разлома). 4. Эксперименты с применением очень частой выборки позволяют расширить понимание процесса и улучшить осведомленность о предвестниках землетрясений и процессе сейсмогенеза, а также усовершенствовать анализ механизма сильных землетрясений и особенностей афтершоков.

Ключевые слова: разлом с изгибом, процесс прерывистого скольжения, землетрясения-дублеты, физическое поле.

\section{INTRODUCTION}

Bending faults is a common type of fault complex. Large earthquakes often involve different seismogenic segments. It is easy to induce a pattern of earthquake doublets by the sequential slip of different segments from bending faults zone. For examples, the earthquake of Tangshan Ms 7.8 and Luanxian Ms 7.1 took place at a small angle of bending faults zone in 1976. The interval between the two events was about 15 hours; the distance was less than $50 \mathrm{~km}$ [Edit Group..., 1982; Lu, Li, 1989; Zheng, Yao, 1993; Du et al., 2010]. From the focal mechanism solution of Wenchuan earthquake of Ms 7.9 in 2008 , it is revealed that the earthquake comprised four earthquake sub-events [Zhang et al., 2009a; Zhang et al., $2009 \mathrm{~b}$; it caused significant damages in Wenchuan Country and Beichuan Country in the central faulting zone. It is believed that this phenomenon is related to the strike change of the central faults, especially, a small angle of fault bending in the vicinity of Anxian Country. It seems to be a significant structural reason that caused so serious losses in Beichuan Country. For the bending structure, interaction between the local stresses and transfer to a large angle of bending faults is complicated, but for a small angle, the interaction is so strong that it can easily induce a series of large earthquakes. The above earthquake examples suggest that the small angle of bending faults should be focused on in studies and assessments of safety in faulting zones.

Some of the previous experimental studies about bending faults were focused on comparable analyses between stages of fault stability and instability. Ma et al. investigated the evolution process of multi-physical fields of the bending faults and analyzed evolution properties of several typical fault complexes and their influences during earthquake rupture [Ma et al., 1995, 1996, 1999; Liu et al., 1995; King, Nabelek, 1985; King, 1986; Andrews, 1989, 1994; Aydin, Du, 1995; Kato et al., 1999; Xing et al., 2004; Poliakov et al., 2002; Kase, Day, 2006; Acharya, 1997]. Kato and his coauthors [Kato et al., 1999; Xing et al., 2004] studied the earthquake doublets on bending faults with the shear strain and the relative fault displacement data from the line strain gauges cross faults in the laboratory and discussed the initial process of the doublets.
Although the authors has declared that the tensile deformation from the gauges cross faults is less than $10 \%$ of the strike slip, according to the theory of elastic deformation, they did not consider the pull-apart action perpendicular to fault strike near bending point, especially in the small angle of fault segment during the fault sliding process. The relative pull-apart displacement from the two plates of faults will be much larger than the elastic deformation component. This implies that their results from the crossfault measurements have lower reliability. In our experiments, we also found the earthquake doublets of bending faults, but our results are different from Kato's results. Moreover, a relationship between stick-slip cycle, magnitudes of stress drop and fault slip against loading rate was not reviewed in the previous studies, and the response characteristics of various observational approaches under high sampling conditions were not discussed. This paper present results of the study of the evolution properties from multi-physical fields of bending faults, especially the features during quick fault slip, with application of a differential type of fault displacement meters, strain tensor measurements and acoustic emission (AE) instruments with high sampling.

\section{SAMPLE DESIGN AND EQUIPMENT FOR OBSERVATIONS}

A number of granodiorite samples were used in the laboratory studies described in this paper. Their sizes were $300 \mathrm{~mm} \times 300 \mathrm{~mm} \times 50 \mathrm{~mm}$. Bending faults were pre-cut along a diagonal direction of the samples; they were made with an angle change of $5^{\circ}$ along fault strike between the upper- and lower- fault in the middle. The sample structure is shown in Fig. 1. To observe the stick-slip process of different fault segments, two differential type of fault displacement gauges were pasted on the upper- and lowerfault segment (symbol F1 and F2 in Fig. 1), respectively. Gauges of this type can be used directly to record the relative slip independent of pull-apart action of faults. They were connected with 8-channel of high-precision sampling apparatus. The sampling frequency of the apparatus was set to $100 \mathrm{~Hz}$ to record slip data, its displacement resolution was about 1um. To analyze the acoustic emission (AE) characteristics during fault stick-slip, sixteen $\mathrm{AE}$ 


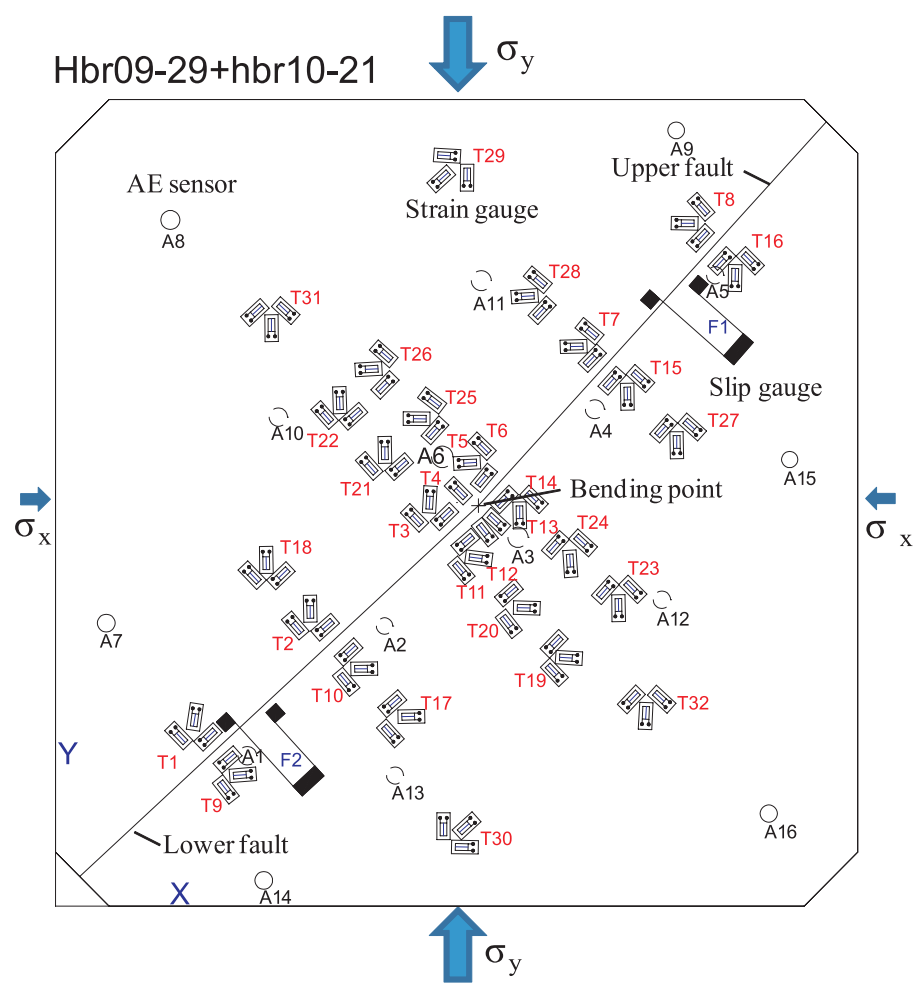

Fig. 1. Sample structure and distribution of sensors. The circles of A1 to A16 are AE sensors, broken circles of A1 to A6 and A10 to A13 are at the front of the sample. Other solid circles are in back. 32 groups of rectangle strain rosettes were numbered from T1 to T32; 4 groups including T16, T17, T21 and T27 were broken during loading; 28 groups of strain tensors were used in the experiment.

Рис. 1. Примерная структура и распределение датчиков. Круги с номерами от А1 до А16 - сенсоры АЭ; разорванные круги A1-A6 и A10-A13 на фронтальной части пробы. Остальные круги показаны черным цветом. 32 группы тензодатчиков пронумерованы от Т1 до T32. 4 группы (в том числе Т16, T17, Т21 и Т27) разломились при нагружении; 28 групп тензодатчиков использовались для получения данных для расчетов.

sensors were installed on the sample surfaces (Symbol A1-A16). Eight of them were on the back surface along strike (dash circles as shown in Fig. 1) to get the AE event process during fault rupture, and the others were installed on the front and back surface (solid circle as shown in Fig. 1) for the three-dimensional $\mathrm{AE}$ location analysis. The $\mathrm{AE}$ sensors were connected with a sixteen-channel of full waveform $\mathrm{AE}$ recorder which received the $\mathrm{AE}$ information generated by micro-fractures inside sample. The A/D conversion resolution of the $\mathrm{AE}$ device was 12bit; maximum sampling frequency was $40 \mathrm{MHz}$; the maximum sampling length was 8k [Liu, Lei, 2003; Liu et al., 2007; Liu et al., 2009]. The sampling rate was $10 \mathrm{MHz}$; the sampling length was $2 \mathrm{k}$. For the analysis of the evolution of strain field during stick-slip process, eighty-seven pieces of line steel strain gauges were pasted on the sample front. Thirtytwo groups of measurement points of strain tensors were arranged with these strain gauges (Symbol T1-T32 as shown in Fig. 1). A 96-channel of strain sampling instru- ment was used to record strain data; its resolution of $A / D$ converter was 16 bit; strain resolution was about $1 \mu \varepsilon$; the sampling rate was set to $100 \mathrm{~Hz}$ during the experiment.

The prepared samples were subject to bi-axially horizontal press. The loading range of this press was up to 120 Tons, which was independently controlled to load and unload with displacement pattern and loading pattern in Xand $\mathrm{Y}$ - direction. Its control frequency was $20 \mathrm{~Hz}$; the sampling rate of the loading and paten displacement was $10 \mathrm{~Hz}$. Besides, due to limitations of the sample size for a large number of sensors, two groups of samples were prepared for the experiments; one group was to record the data of acoustic emission signals and fault displacement, and the second group was to records the strain data.

\section{EXPERIMENTAL RESULTS}

\subsection{RESPONSES FROM SHEAR STRESS AND FAULT DISPLACEMENT}

In the experiment, the loading process was as follows: first, the load of X- and Y-direction was synchronously applied to 6.5 Tons (the pressure is $5 \mathrm{MPa}$ ) with the speed of $50 \mathrm{~kg} / \mathrm{s}$ by controlling loading pattern, and then Xdirection was kept at the 6.5 Tons level, Y-direction was transferred to the controlling pattern of paten displacement and continued to applied pressure with the loading rate of $0.5 \mathrm{um} / \mathrm{s}, 0.1 \mathrm{um} / \mathrm{s}, 0.05 \mathrm{um} / \mathrm{s}$ and $0.01 \mathrm{um} / \mathrm{s}$, respectively. The data of several stable stick-slip events were recorded under different loading rates.

In data analysis, an average shear stress was calculated from stresses along the diagonal direction of sample, the curves of shear stress and fault slip are shown in Fig. 2. For the whole process of stick-slip events, an average shear stress shows hardening properties with loading in-

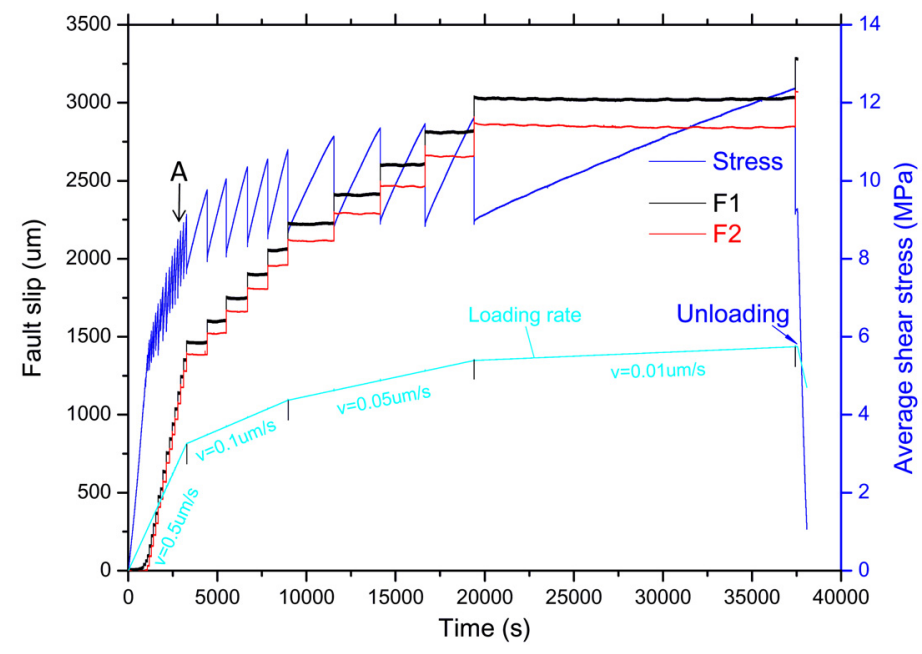

Fig. 2. Loading curves and fault displacement versus time.

Рис. 2. Графики деформации и смещений по разломам во времени. 

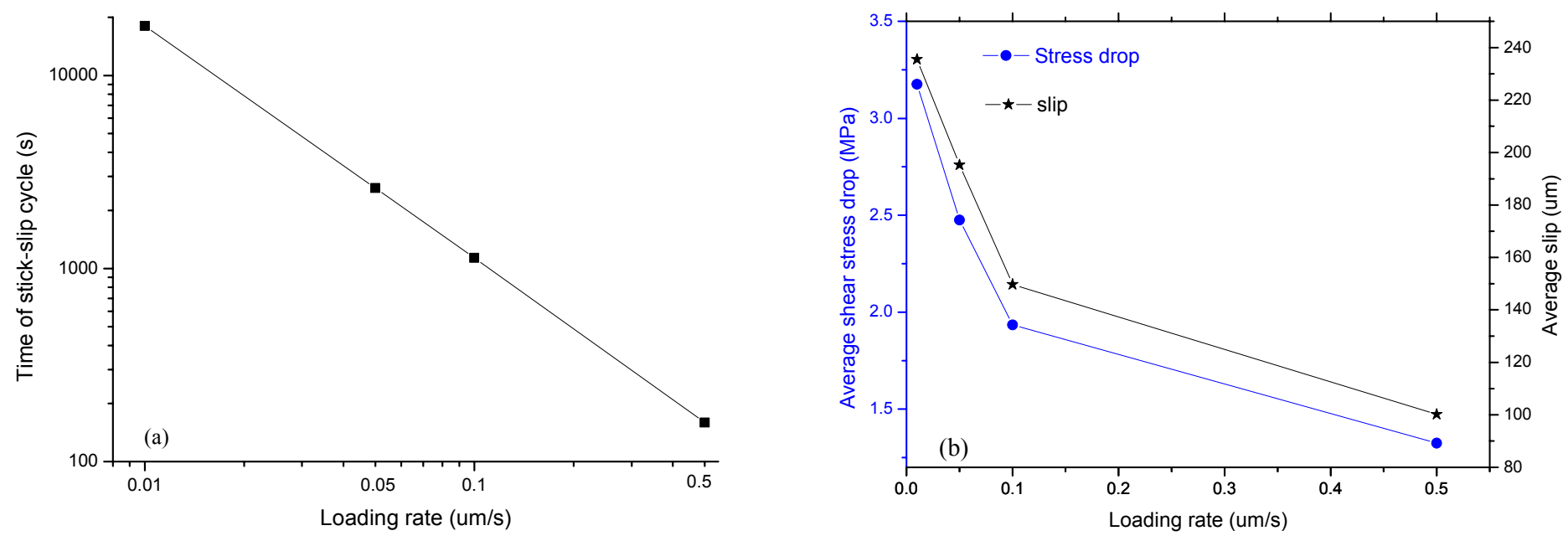

Fig. 3. Stick-slip cycle (a), slip and stress drop (b) against loading rate.

Рис. 3. Цикл прерывистого скольжения (a), скольжения и снижения напряжения $(b)$ относительно скорости нагружения.

crement under a certain constant loading rate. The longer is the stick-slip period, the lower is the loading rate (see Fig. 3a). For static results from all the stick-slip events, we find that there is a good linear relationship between the logarithm of average stick-slip cycle and the average stress drop.

The line relationship provides for estimation of the time of the earthquake activity in the faulting zone. The average stress drop and the fault slip also decrease with the increment of the loading rate (see Fig. 3b). However, the static relationship between both of them and the loading rate is not clear yet and needs further studies.

The change of fault slip is unclear before fault slip during loading, and slips mostly occur in two sub-event, not in one, during bending fault instability. Few slips contained three sub-events. Considering Event A (see Fig. 2) as an example, the typical slip curves of Event $\mathrm{A}$ are shown in Fig. 4; it contains two sub-events (A1 and A2). During the first slip of faults, the upper and lower fault started to synchronously slip and moved about $72.6 \mu \mathrm{m}$ and $81.6 \mu \mathrm{m}$ in the 40 micro-second. Then there was a pause of about $152 \mathrm{~ms}$ and transfer to the second slip event (A2); the faults kept moving forward for about $36.6 \mu \mathrm{m}$ and $33.0 \mu \mathrm{m}$ during the time period of $37 \mathrm{~ms}$. In sub-event A1, the slip speed of the upper and lower fault was about $1.7 \mathrm{~mm} / \mathrm{s}$ and $2.0 \mathrm{~mm} / \mathrm{s}$, respectively; the speed changed to $1.0 \mathrm{~mm} / \mathrm{s}$ and $0.9 \mathrm{~mm} / \mathrm{s}$ for sub-event A2. The total slip was about $106.2 \mathrm{um}$ for the bending faults.

\subsection{THE EVOLUTION PROPERTY FROM STRAIN FIELD}

The strain tensor of each strain measurement point (T1-T32) was composed of three pieces of line strain gauges pasted on the sample surface, according to rectan- gular rosette type (see Fig. 1). Data from four gauges tensor points (T16, T17, T21 and T27) are not used for calculations because some of the gauges were broken during loading; thus, data from 28 strain tensor points are analyzed in this paper. Fig. 5 shows typical stick-slip curves from the average strain and maximum shear strain along fault strike as an example of the stick-slip process of Event A (the time is set to zero when the last stick-slip event stopped). In this paper, the average strain from compres-

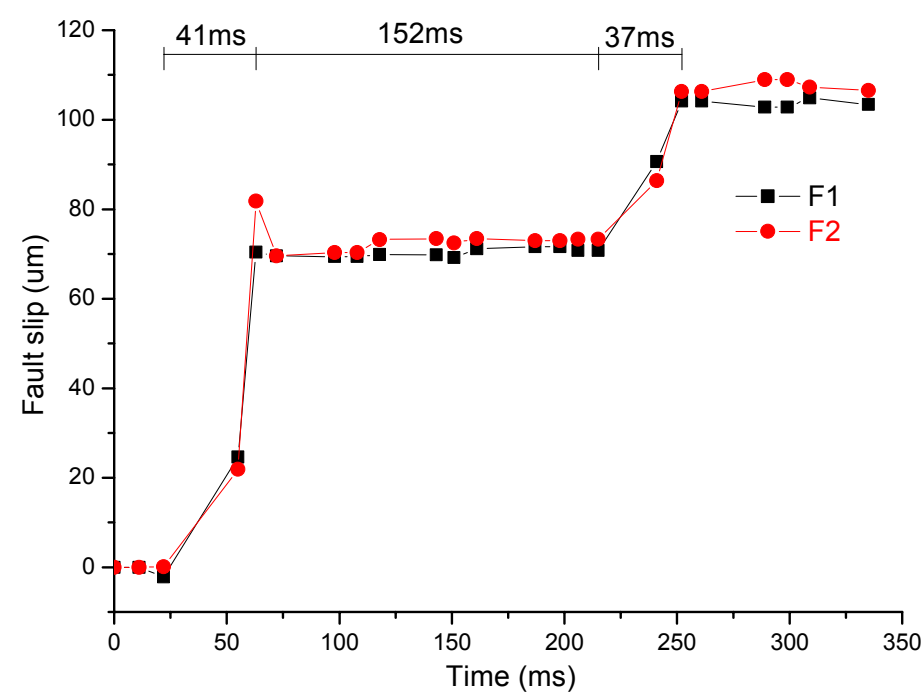

Fig. 4. Typical slip process of instability of Event A ( $\mathrm{v}=0.5 \mathrm{um} / \mathrm{s})$.

Рис. 4. Типичный процесс нестабильности со скольжением. Событие А ( $\mathrm{v}=0.5 \mathrm{mм} / \mathrm{ceк})$. 



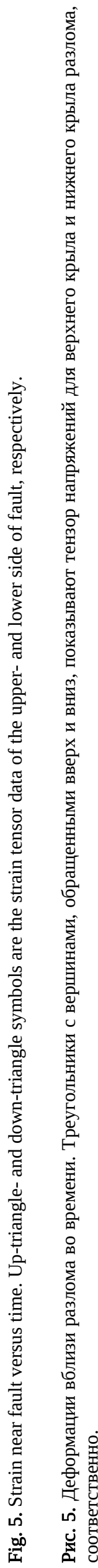

$a$
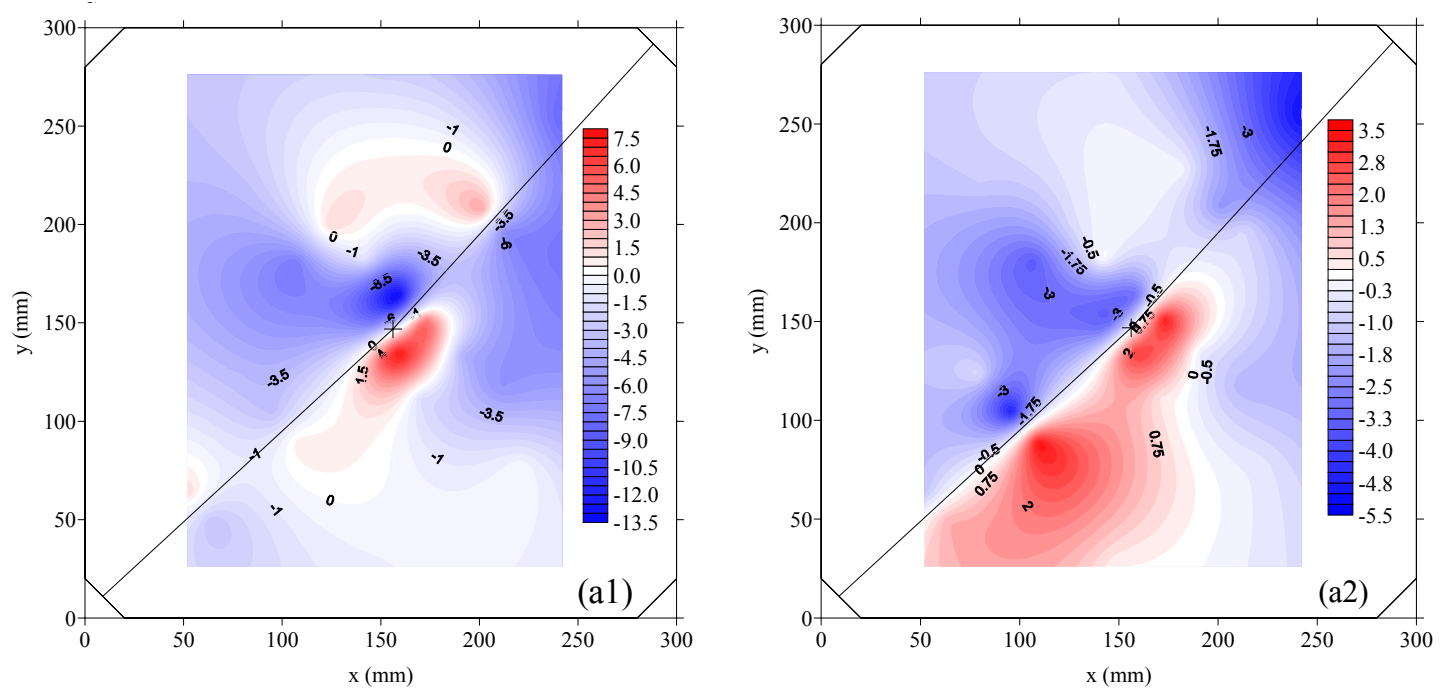

$b$
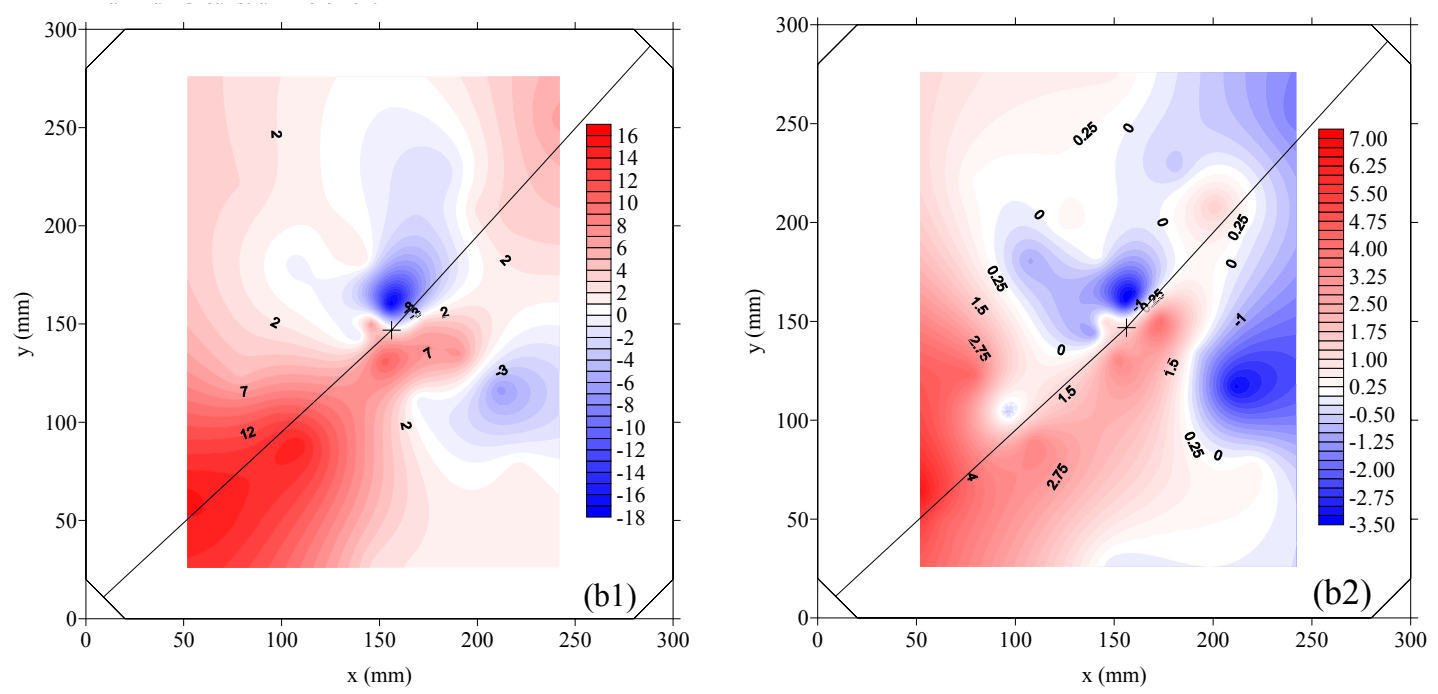

Fig. 6. Strain increment field during slip. $a$ - average strain map; $b$ - maximum shear strain map. Fig. a1 and Fig. a2 show the average strain increment field of Event A1 and Event A2. Fig. b1 and Fig. b2 show the maximum shear strain increment field of Event A1 and Event A2.

Рис. 6. Поле усиления деформаций в процессе скольжения. $a$ - карта деформаций среднего уровня; $b$ - карта максимальных деформаций. Рис. а1 и рис. а2 - поле среднего увеличения деформации при событии А1 и событии A2, соответственно. Рис. b1 и рис. b2 - поле максимального увеличения деформации при событии А1 и событии А2, соответственно.

sion stress is positive, the shear strain in a clockwise direction is positive; thus, it can be concluded that dextral shear is positive. Before the faults slip, strain hardening phenomena were also observed just like average shear stress of faults during loading. Most of the strain tensor points on both sides of faults are mainly compressive; the peak strain may be up to 15 micro-strains along fault strike. However, the two tensor points (T13 and T14) recorded the tensile stage because of the influence from fault bending, the corresponding maximum average tensile strain is about -7.5 micro-strain (as shown in Fig. 5b1). The relative fault slip is with sinistral domination, but at the tensor points (T5 and T6) near the fault bending, mainly right-lateral shear deformation occurs.

Strain curves from the strain points along the fault strike are shown in Fig. 5 (a2) and (b2) for the fast slip process within 0.6 second. The strain analysis results agree with that of fault displacement; doublets phenomena also are observed; on the other hand, two sub-events of instabilities during a whole slip. The detailed slip process is as follows: In a new loading cycle, as loading time lasted 57.11 seconds, the strain tensor along the fault strike started to soften and kept about 1.3 seconds. It may mean that the fault exists at the nucleation stage, but the loading strength is not enough to cause the slip instability of the faults. At 57.14 seconds, the first fast movement of faults 

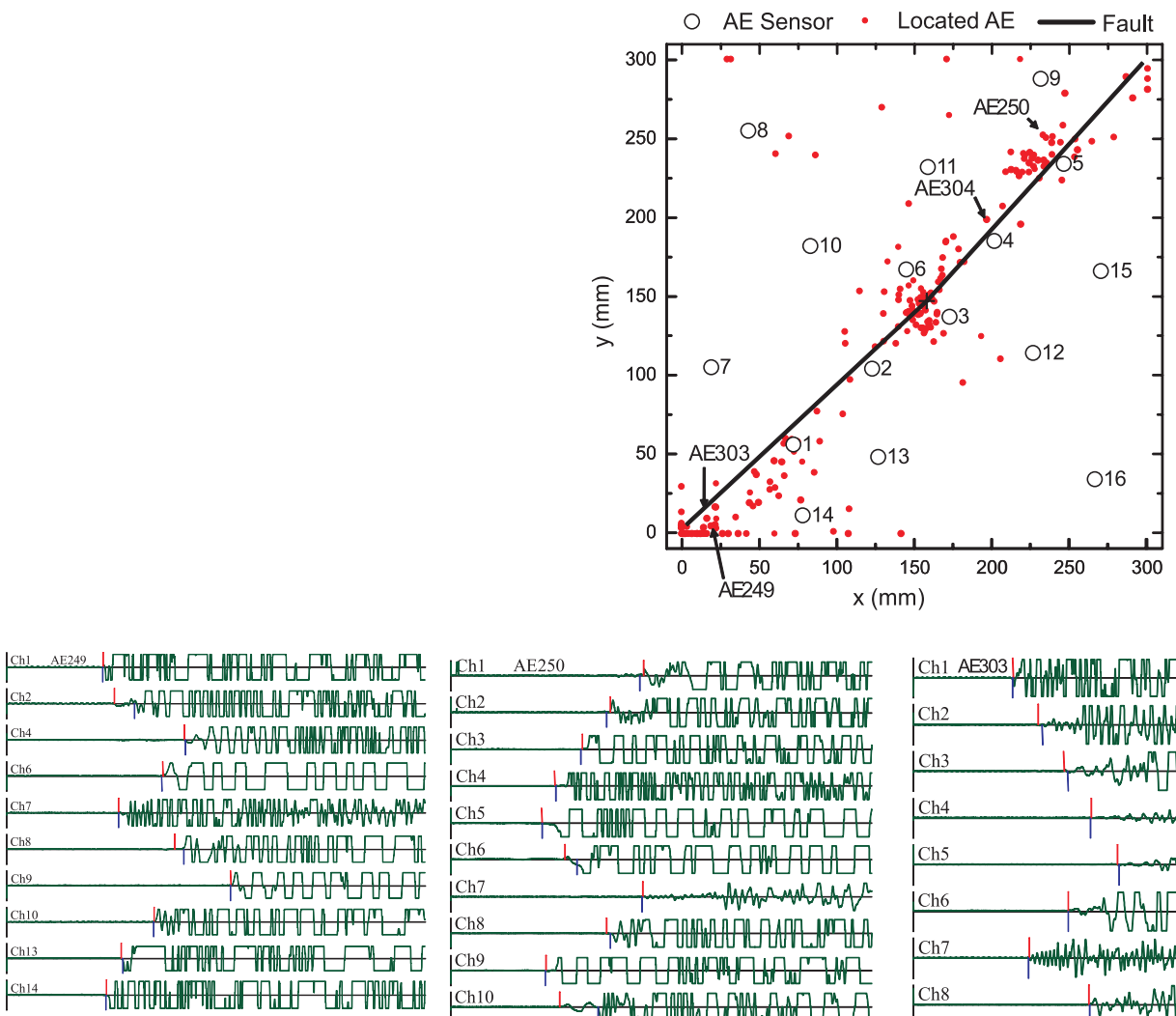

AE249

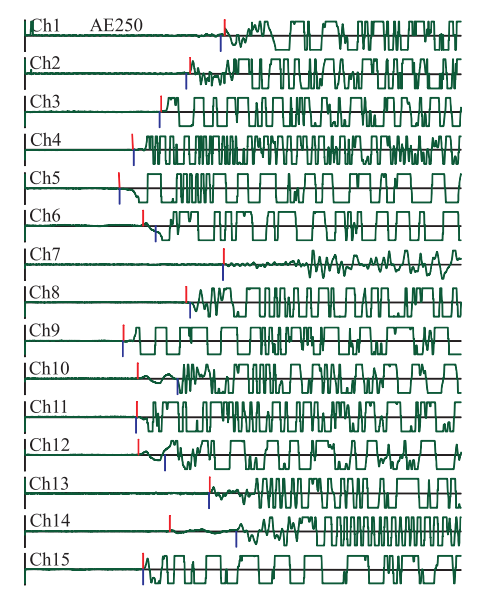

AE250

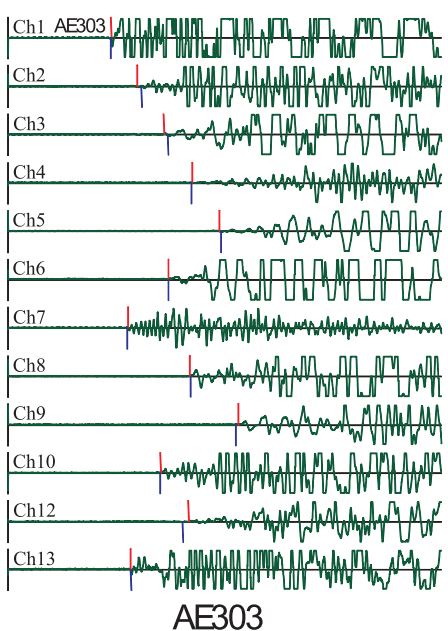

AE303

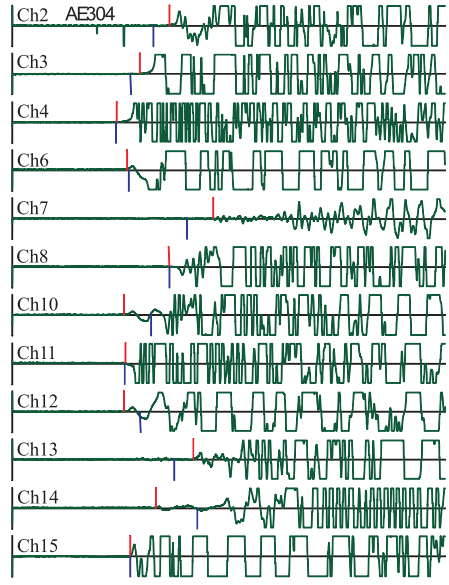

AE304

Fig. 7. AE sources and typical corresponding waveforms.

Рис. 7. Источники акустической эмиссии и соответствующие типичные волновые формы.

occurred (Sub-event A1 as shown in Fig. 5 (a1)), and stopped up to 57.16 seconds. However, the average strain returned to a stable level until 57.19 seconds. The second nucleation stage started at 57.21 seconds, and lasted for about 0.19 seconds. And then the second rapid movement (Sub-event A2 in Fig. 5 (a2)) occurred at 57.40 s, and stopped at 57.42 seconds. The strain value recovered at a stable level until 57.5 seconds. At that time, the whole sliding process was over, and transfer to the next loading cycle took place.

At the first rapid slide stage, the high value of average strain increment mainly dispersed near tensor points T5 and T6 (see Fig. 1 and Fig. 6(a)), the corresponding increments were about 13.0 micro-strains. However, the higher maximum shear stress increment appeared in these three areas (T1 to T2, T5 to T6, and T9 to T11, see Fig. 1 and Fig. 6 (b)), the corresponding maximum shear strain increment were about $13.1,17.4$ and 13.4 micro-strains, respectively. The increments of other points are less than 10 micro-strains. This indicates that energy release areas are on the lower fault segment and near bending point during the process of fault instability containing two slip subevents. The full field map of strain increment is shown in Fig. 6. The field maps of the average strain increment field are shown in Fig. 6a (positive values represent relative compression, negative values for relative extension). The field maps of maximum shear strain field are shown in Fig. $6 \mathrm{~b}$ (positive values represent relative dextral shearing, negative value show sinistral shearing). As sub-event A1 occurred, the tensile strain relaxation mainly concentrated near the bending point and formed a significant area of relative extension. At the lower fault segment, a shear strain concentrated area formed. The average strain increment at this stage significantly changed in the amount at the bending point, and the maximum shear strain field was mainly concentrated in the lower fault segment. When the second slide was initiated, the relative extrusion zone shifted towards the lower fault segment. 


\subsection{ACOUSTIC EMISSION (AE) PROPERTIES}

From the results of three-dimensional AE locations shown in Fig. 7, we find that AE sources were mainly scattered in the three regions near the bending point on the upper- and lower- faults segments, few sources appeared on other places during stick-slip. The located AE events took on obvious transformation property along the fault strike. For examples, Event AE250 and AE 304 on the upper fault segment initiated about late 0.014 second after Event AE249 and AE 303 was located on the lower one, respectively. This indicates that the earthquake doublets were also revealed by the AE technique. The corresponding $\mathrm{AE}$ waveforms from the four located events are illustrated in Fig. 7. Most of waveforms were excessive during fault sliding. This suggests that the fault instability is accompanied by strong elastic energy release by earthquakes.

\section{RESULTS AND DISCUSSION}

The evolutional properties of multiphysical field were investigated with application of the loading, fault displacement, strain field and acoustic emission techniques. Some primary conclusions are as follows:

(1) A good negative correlation is revealed between the logarithm stick-slip cycle and the loading rate. This experimental result can contribute to the knowledge on the regularity of occurrence of large earthquake in terms of time. Although the stress drops and fault displacement decreases with the increase of the loading rate, the quantitative relationship between them is not clear yet and thus needs further studies.

(2) Most of the stick-slip events during instabilities are doublets generated by fault strike change in experiments, few are single. The results from the above observations of the multi-physical fields confirm the phenomena. The active strength from the first sub-event is obviously stronger than that of the second sub-event. This suggests that the release of elastic energy will primarily take place in the main shock. This conclusion is useful for understanding the mechanism of tectonic earthquakes and the features of related aftershocks.

(3) Although the sampling rate was similar for different observational approaches applied in this study, it was revealed that co-seismic response was different. For examples, the clear changes from strain gauges were measured before faults moved, but the changes from fault displacement were not found. This observation suggests that the different sensitivities of responses before and after earthquake are different. The precursor information from the strain measurements is better, which distributed along the fault.

(4) The physical properties obtained with different sampling frequency are not coincident, especially during quick fault sliding. In the experiment, the doublets can not be be distinguished by $10 \mathrm{~Hz}$ loading data, but they were revealed by fault displacement and strain data with $100 \mathrm{~Hz}$ sampling. The acoustic emission data with $10 \mathrm{MHz}$ sampling can help clearly distinguish the micro-fracture process between different fault segments.

(5) The current observational results provide useful information on the doublets of bending faults; however, the quick instability process has not been observed yet in detail. More detailed investigations of the dynamics of fault instabilities with higher sampling rates should be conducted.

In this paper, the relationship between stick-slip, stress drop and fault displacement against loading rate is revealed; it can be useful for studies of seismic risks and the regularity of large earthquake recurrences in faulting zones. Besides, it contributes to a deeper understanding of the influence of fault strike on seismogenic mechanism, seismic process and co-seismic responses studies by different measurement methods, which revealed the doublets of stick-slip from bending faults experiments. There grounds to expect that further studies will provide for a more comprehensive understanding of earthquake dynamics on the basis of detailed evidences revealed in the laboratory.

\section{ACKNOWLEDGEMENTS}

This paper was supported by State Natural Science Foundation of China (40872129 and 40802044), National Key Basic Research and Development Program of China (2004CB418405) and China postdoctoral scientific foundation project (20070420414). The authors appreciate discussions and advices from Professor Liu Liqiang and Liu Peixun, Institute of Geology, China Earthquake Administration.

\section{REFERENCES}

Acharya H.K. Influence of Fault Bends on Ruptures // Bulletin of the Seismological Society of America. 1997. V. 87. № 6. P. 16911696.

Andrews D.J. Mechanics of fault junctions // Journal of Geophysical Research. 1989. V. 94. № B7. P 9389-9397. doi:10.1029/ JB094iB07p09389.

Andrews D.J. Fault geometry and earthquake mechanics // Annali di Geofisica. 1994. V. 37. № 6. P. 1342-1348.

Aydin A., Du Y.J. Surface rupture at a fault bend: the 28 June 1992 Landers, California earthquake // Bulletin of the Seismological Society of America. 1995. V. 85. № 1. P. 111-128.

Du C.X. Xie F. R., Zhang $Y$. et al. 3D modeling of dynamic fault rupture and strong ground motion of the 1976 Ms 7.8 Tangshan earthquake // Chinese Journal of Geophysics. 2010. V. 53. № 2. P. 290304 (in Chinese).

Edit Group of the 1976 Tangshan earthquake in China Earthquake Administration. The 1976 Tangshan earthquake. Beijing: Earthquake Press, 1982. P. 33-70 (in Chinese).

Kase Y., Day S.M. Spontaneous rupture processes on a bending fault // Geophysical Research Letters. 2006. V. 33. L10302. doi:10.1029/ 2006 GL025870. 
Kato N., Satoh T., Lei X.L., Yamamoto K., Hirasawa T. Effect of fault bend on the rupture propagation process of stick-slip // Tectonophysics. 1999. V. 310. № 1-4. P. 81-99. doi:10.1016/S00401951(99)00149-3.

King G., Nabelek $J$. Role of fault bends in the initiation and termination of earthquake rupture // Science. 1985. V. 228. № 4702. P. 984987. doi:10.1126/science.228.4702.984.

King G.C.P. Speculation on the geometry of the initiation and termination processes of earthquake rupture and its relation to morphology and geological structure // Pure and applied geophysics. 1986. V. 124. № 3. P. 567-585. doi:10.1007/BF00877216.

Liu L.Q., Lei X.L. An acoustic emission acquiring system with ultrahigh speed parallel net // Seismology and Geology. 2003. V. 25. № 3. P. 477-480 (in Chinese).

Liu L.Q., Ma J., Ma S.L. Characteristics and evolution of background strain field on typical structure models // Seismology and Geology. 1995. V 17. № 4. P. 349-356 (in Chinese).

Liu P.X., Liu L.Q., Chen S.Y. et al. Software for three-dimensional location of acoustic emission in laboratory // Seismology and Geology. 2007. V. 29. № 3. P. 674-679 (in Chinese).

Liu P.X., Liu L.Q., Huang Y.M. et al. Robust arithmetic for acoustic emission location // Chinese Journal of Rock Mechanics and Engineering. 2009. V. 28. № S1. P. 2760-2764 (in Chinese).

Lu Z., Li Z.T. Focus process of Tangshan earthquake maybe existing barriers // Northeastern seismological research. 1989. V. 5. № 1. P. 43-51 (in Chinese).

Ma J., Liu L.Q., Ma S.L. The evolution and instability characteristics form physical fields of Fault geometry structures // Acta Seismologica Sinica. 1996. V. 18. № 2. P. 200-207 (in Chinese).

Ma J., Liu L.Q., Ma S.L. Fault geometry and departure of precursors from epicenter // Earthquake Research in China. 1999. V. 15. № 2. P. 106-115 (in Chinese).

Ma J., Ma W.T., Ma S.L. et al. Experimental study and numerical simulation on physical fields during the deformation of a $5^{\circ}$ bend fault // Seismology and Geology. 1995. V. 17. № 4. P. 318-326 (in Chinese).

Poliakov A.N.B., Dmowska R., Rice J.R. Dynamic shear rupture interactions with fault bends and off-axis secondary faulting // Journal of Geophysical Research. 2002. V. 107. № B11. 2295. doi:10.1029/ 2001JB000572.

Xing H.L., Mora P., Makinouchi A. Finite element analysis of fault bend influence on stick-slip instability along an intra-plate fault // Pure and Applied Geophysics. 2004. V. 161. № 9-10. P. 20912102. doi:10.1007/s00024-004-2550-1.

Zhang Y., Feng W.P., Xu L.S., Zhou C.H., Chen Y.T. Spatio-temporal rupture process of the 2008 great Wenchuan earthquake // Science China Series D: Earth Sciences. 2009. V. 52. № 2. P. 145-154. doi:10.1007/s11430-008-0148-7.

Zhang Y., Xu L.S., Chen Y.T. Spatio-temporal variation of the source mechanism of the 2008 great Wenchuan earthquake // Chinese Journal of Geophysics. 2009. V. 52. № 2. P. 379-389 (in Chinese).

Zheng T.Y., Yao Z.X. Source process study of the Tangshan earthquake using the near-field records // Chinese Journal of Geophysics. 1993. V. 36. № 2. P. 174-184 (in Chinese).
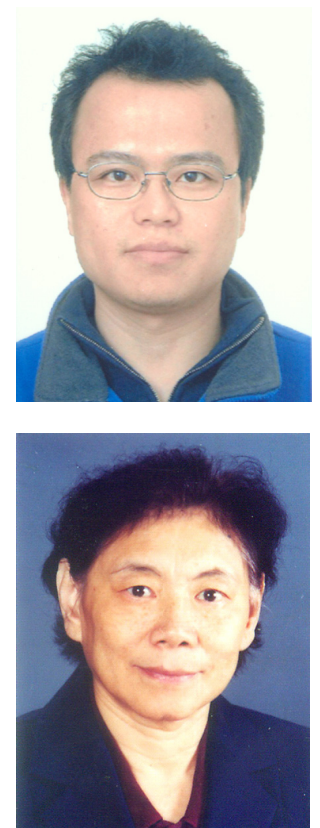

Guo Yanshuang

State key laboratory of earthquake dynamics, Institute of Geology, China Earthquake Administration 100029, Beijing, China

e-mail: guoyshig@gmail.com

\section{Гуо Юаншуан}

Лаборатория динамики землетрясений, Институт геологии, Китайская администрация по землетрясениям 100029, Пекин, Китай

e-mail: guoyshig@gmail.com

\section{Ma Jin}

State key laboratory of earthquake dynamics, Institute of Geology, China Earthquake Administration

100029, Beijing, China

$\triangle$ e-mail: dzjmajin@gmail.com

\section{Ма Джин}

Лаборатория динамики землетрясений, Институт геологии, Китайская администрация по землетрясениям 100029, Пекин, Китай

$\triangle$ e-mail: dzjmajin@gmail.com 
Y.S.H. Guo et al.: The experimental study on stick-slip process...

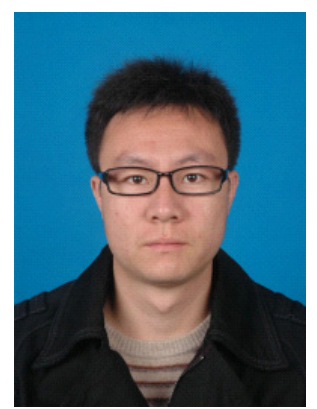

\section{Yun Long}

State key laboratory of earthquake dynamics, Institute of Geology, China Earthquake Administration 100029, Beijing, China

e-mail: yunl1985@126.com

\section{Юн Лонг}

Лаборатория динамики землетрясений, Институт геологии, Китайская администрация по землетрясениям 100029, Пекин, Китай

e-mail: yunl1985@126.com

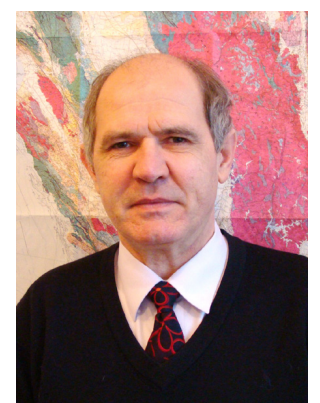

Bornyakov Sergei A., Candidate of Geology and Mineralogy, Senior Researcher, Lab. of Tectonophysics Institute of the Earth's Crust, Siberian Branch of RAS 664033, Irkutsk, Lermontov street, 128, Russia e-mail: bornyak@crust.irk.ru

Борняков Сергей Александрович, канд. геол.-мин. наук, с.н.с., лаб. тектонофизики Институт земной коры СО РАН

664033, Иркутск, ул. Лермонтова, 128, Россия

e-mail: bornyak@crust.irk.ru 